\title{
Trends and Volatilities in Heterogeneous Patent Quality in Taiwan
}

\author{
Wen-Cheng Lu ${ }^{1 *}$, Jong-Rong Chen ${ }^{2}$, I-Hsuan Tung ${ }^{3}$
}

\begin{abstract}
This study analyzes patent trends and volatilities for three heterogeneous quality patents in the Taiwan patent system from January 1973 to June 2006. The estimated models are symmetric $\operatorname{GARCH}(I, I)$ and asymmetric $\operatorname{EGARCH}(I, I)$, providing full sample, rolling sample, and out-of-sample evidence. Three different patent types exhibit increasing trends, using monthly time series data from our samples. "New design" patents also show time-varying volatility but other types of patents fail to reject the ARCH LM test. Findings show the asymmetric EGARCH $(I, I)$ model suitable for "new design" patent type through out of sample forecasts.management.
\end{abstract}

Keywords: patent trends; quality patents; Taiwan.

\footnotetext{
* Correspondence to: Wen-Cheng, Lu, Department of Economics, Ming Chuan University, Taoyuan County, 333, Taiwan. TEL: 886-3350700I ext. 3452, E-mail:bunshou.lu@msa.hinet.net

I Department of Economics, Ming Chuan University, Taoyuan County, Taiwan.

${ }^{2}$ Graduate Institute of Industrial Economics, National Central University, Chungli, Taiwan

${ }^{3}$ Graduate Institute of Industrial Economics, National Central University, Chungli, Taiwan
} 


\section{Introduction}

Patent registration and application trends frequently describe a country's technological capabilities, and act as a proxy for innovation (see e.g. Pavitt, 1988; Patel and Pavitt, 1995; Griliches et al., 1989; Marinova, 200I). Most research on granted patents in the USA examines snapshot images representing patent activities for a particular time period, based on a single-year or aggregated annual information base. Volatilities and Trend for patents have also been analyzed in the literature (see for example, Chan et al., 2004; McAleer et al., 2006; Marinova and McAleer, 2002; Marinova and McAleer, 2003, Hoti and McAleer, 2006). Hall (2004) investigates that a time series analysis of patents reveals a very significant structural break between 1983 and 1984 (data is drawn from Hall et al. (2002, 2005)). Most research on trends and volatilities of granted patents focus on patent ratio for different countries at the US PTO (the ratio of the number of patents lodged at the US PTO from a given country to the total number of patents registered in the USA). Variations in patent share are of interest because patent share is a leading indicator of technical innovation. Moreover, knowledge of the stochastic process underlying patent share variations provides crucial information regarding risk associated with innovative activity over time.

Patents registered by the US Patent and Trademark Office (PTO) represent an excellent source of information regarding technological strengths and market ambitions for countries (see for example, Chen et al., 2004) but rarely see patent research registered in other countries, especially in developing countries. This paper examines trends and volatilities in patent applications in Taiwan using monthly time series data from 1973 to 2006. Patent applications approach state-of-the-art which is the highest level of development, technique, or scientific field, achieved at a particular time. This work divides patents into three heterogeneous categories by different patent quality-"Invention", "new utility model", and "new design". Different types of patents represent distinct innovation quality in the Taiwan patent system. "Invention" patents are more important and higher quality than "new utility model" and "new design" patents which are a relatively small or applicative innova- tion. Taiwan patent system characteristics are listed in Table I. Thus, different quality patents may exhibit dissimilar patterns of trends and volatilities. This paper is the first research to investigate trends and volatilities for different quality patents in contrast to previous empirical researches (in contract to Chan et al., 2004; McAleer et al., 2006; Marinova and McAleer, 2002; Marinova and McAleer, 2003, Hoti and McAleer, 2006). Second, the sample period selected for empirical analysis covers all granted patents with lodged application dates between January 1973 and June 2006 (more than thirty years). The empirical analysis in this study is interesting to contrast with previous studies using US PTO data during 1975 and 1998. Third, volatilities are fundamental to risk management in financial models that evaluate risk spillovers and describe the risk-return trade-off, such as in portfolio selection models and pricing of primary and secondary derivatives. The estimation of volatilities associated with patents would seem to be a crucial first step in this direction. Fourth, Goel (1999) states that government supports the patent system as a tool to correct market imperfections, thereby prohibiting imitating firms to benefit from costly technologies developed elsewhere. The patent system assures appropriable returns to inventors, and benefits society by revealing information to the public after patent expiry. Patent laws were introduced in the USA in the 1780s. The Taiwan patent system is different from the American patent system. This investigation first examines trends and volatilities in patent applications in Taiwan in contrast to that in the US patent system.

We report a number of interesting findings: first, the estimated models are symmetric $\mathrm{GARCH}(\mathrm{I}, \mathrm{I})$ and asymmetric EGARCH $(I, I)$. These provide full sample, rolling sample, and out-of-sample evidence. The Lagrange multiplier test of no $\mathrm{ARCH}$ effects shows that "new design" patents exhibit time-varying volatility but "new utility model" and "invention" patents cannot reject the null hypothesis of no ARCH effects. Second, total patent applications in Taiwan show a generally increasing trend. The trends clearly slope upward for the three types of patents. Finally, this study finds the asymmetric $\operatorname{EGARCH}(I, I)$ model suitable for 'new design' patent type throughout sample forecasts. 
This paper is planned as follows. Section 2 discusses the time varying $\mathrm{GARCH}(\mathrm{I}, \mathrm{I})$ and $\operatorname{EGARCH}(\mathrm{I}, \mathrm{I})$ models. Section 3 describes the data used. Section 4 presents our empirical results. Section 5 gives some concluding remarks.

\section{Alternative Models of Volatility}

This section models patent application volatility in Taiwan. A new method based on Engle's (1982) pathbreaking idea of capturing time-varying volatility using the autoregressive conditional heteroscedasticity $(\mathrm{ARCH})$ model can be applied to analyze patent applications. Subsequent developments have formed the ARCH family of models (see, for example, the useful surveys of Bollerslev et al., 1992; Bollerslev et al., 1994; Li et al., 2002). The generalized ARCH (GARCH) model of Bollerslev (1986) has been the most popular of these models, especially for financial data analysis. This work uses the EGARCH model to accommodate asymmetric behavior between negative and positive shocks (or time series movements).

Analyzing patent volatility can be quite different from using GRACH models for Finance and Economics, in which the main interest is pricing financial products. Volatility is an inherent financial market characteristic, relating to the established nature and modes of operation. Estimated volatilities are fundamental to risk management in financial models that describe the risk-return trade-off. However, patents are a relatively new phenomenon, expected to have considerable impact on industrial economics, with increasing concerns about intellectual property rights and knowledge capital.

This paper investigates patent application volatility in Taiwan, in addition to patenting trends already described, by estimating the $\operatorname{AR}(I)-G A R C H(I, I)$ and $\operatorname{EGARCH}(I, I)$ models, in which the conditional mean of the patent application follows an $A R(I)$ process.

Consider the stationary GARCH $(I, I)$ model for the patent applications, $y_{t}$ :

$$
y_{t}=\phi_{1}+\phi_{2} y_{t-1}+\phi_{3} t+\varepsilon_{t},\left|\phi_{2}\right|<1
$$

for $t=1,2, \ldots, n$, where the shocks (or movements in the patent applications) are given by:

$$
\begin{aligned}
& \varepsilon_{t}=\eta_{t} \sqrt{h_{t}}, \quad h_{t} \sim \text { iid N(0,1) } \\
& h_{t}=\omega+\alpha \varepsilon_{t-1}^{2}+\beta h_{t-1}
\end{aligned}
$$

And $\omega>0, \alpha \geq 0, \beta \geq 0$ are sufficient conditions to ensure that the conditional variance $h_{t}>0$, the ARCH (or $\alpha$ ) effect stands for short run shock persistence, while the GARCH (or $\beta$ ) effect indicates shock contribution to long-run persistence (namely, $\alpha+\beta$ ). In Equations $(I) \sim(3)$, the parameters are typically estimated by the maximum likelihood method to obtain quasi-maximum likelihood estimators (QMLE) in the absence of normality of $\eta_{t}$. The conditional loglikelihood function is given as follows:

$$
\sum_{t} l_{t}=-\frac{1}{2} \sum_{t} \log h_{t}+\frac{\varepsilon_{t}^{2}}{h_{t}}
$$

Ling and McAleer (2003) show that the QMLE for $\operatorname{GARCH}(p, q)$ is consistent if the second moment is finite, that is, $E\left(\varepsilon_{t}^{2}\right)<\infty$. Ling and $\mathrm{Li}$ (1997) show that the local QMLE for GARCH $(\mathrm{p}, \mathrm{q})$ is asymptotic normal if the fourth moment is finite, that is, $E\left(\varepsilon_{t}^{4}\right)<\infty$, and the model is stationary and ergodic if $E\left(\varepsilon_{t}^{2}\right)<\infty$. Using results from Ling and $\mathrm{Li}$ (1997) and Ling and McAleer (2002a, b), the necessary and sufficient condition for second moment existence of $\varepsilon_{t}$ is $\alpha+\beta<1$ and, under normality, the necessary and sufficient condition for forth moment existence is $(\alpha+\beta)^{2}+2 \alpha<1$.

The Exponential GARCH (EGARCH $(I, I))$ model (Nelson, 1991) captures asymmetric behavior in conditional variance, namely:

$$
\log h_{t}=\omega+\alpha\left|\eta_{t-1}\right|+\gamma \eta_{t-1}+\beta \log h_{t-1}, \quad|\beta|<1
$$


Some distinct differences between EGARCH and GARCH are present as follows: (I) EGARCH is a logarithm model of conditional variance, implying no restrictions on parameters to ensure $h_{t}>0$; (2) $|\beta|<1$ is likely a sufficient condition for existing moments and consistency of QMLE for EGARCH(I,I) (McAleer, et al., 2007; Shephard, 1996).

\section{Data}

The US has firmly adopted the patent system for over two centuries, as a mechanism for protecting intellectual property and stimulating innovative activities. A government supports the patent system as a tool to correct market imperfections, thereby allowing imitating firms to benefit from costly technologies developed elsewhere.
The system assures appropriable returns to inventors, and benefits society by revealing information after patent expiry.

The sample period selected for empirical analysis covers all patents with lodged application dates between January 1973 and June 2006. This study obtained patent data from the official Taiwan PTO (TWPAT) Internet webpage using the search engine available (http://www.twpat.com/webpat/). Taiwan patent systems comprise three types of patents: "invention", "new utility model", and "new design" patents. Taiwan patent characteristics include patent validity, examination, filing requirements and so on. This paper summarizes Taiwan patent system characteristics in Table I.

\begin{tabular}{|c|c|c|c|}
\hline & “invention" patent & $\begin{array}{c}\text { " new utility model" } \\
\text { patent }\end{array}$ & "New design" patent \\
\hline Patent valid & 20 years & 10 years & 12 years \\
\hline Examination & $\begin{array}{l}\text { Substantive examination on } \\
\text { request within three years } \\
\text { from filing date }\end{array}$ & $\begin{array}{l}\text { Formality examination ap- } \\
\text { plications only. When claim- } \\
\text { ing utility model patent } \\
\text { right, a technical report } \\
\text { should be requested to } \\
\text { Taiwan IPO }\end{array}$ & $\begin{array}{l}\text { Substantive, automatic ex- } \\
\text { amination }\end{array}$ \\
\hline Filing requirements & $\begin{array}{l}\text { I. Any language is accepta- } \\
\text { ble for acquiring a filing } \\
\text { date. } \\
\text { 2. Power of Attorney (can } \\
\text { be submitted within four } \\
\text { months of the filing date) } \\
\text { 3. Assignment (if any, can be } \\
\text { submitted within four } \\
\text { months of the filing date }\end{array}$ & $\begin{array}{l}\text { I. Any language is accepta- } \\
\text { ble for acquiring a filing } \\
\text { date. } \\
\text { 2. Power of Attorney (can } \\
\text { be submitted within four } \\
\text { months of the filing date) } \\
\text { 3. Assignment (if any, can be } \\
\text { submitted within four } \\
\text { months of the filing date }\end{array}$ & $\begin{array}{l}\text { I. Any language is accepta- } \\
\text { ble for acquiring a filing } \\
\text { date. } \\
\text { 2. Power of Attorney (can } \\
\text { be submitted within three } \\
\text { months of the filing date) } \\
\text { 3. Assignment (if any, can be } \\
\text { submitted within three } \\
\text { months of the filing date }\end{array}$ \\
\hline
\end{tabular}

Table I. Taiwan patent system characteristics 


\begin{tabular}{|l|c|c|c|c|}
\hline & Total patents & $\begin{array}{c}\text { “invention" } \\
\text { patents }\end{array}$ & $\begin{array}{c}\text { “new utility } \\
\text { model" patents }\end{array}$ & $\begin{array}{c}\text { "new design" } \\
\text { patents }\end{array}$ \\
\hline Total patents & 1.000 & 0.977 & 0.985 & 0.931 \\
\hline $\begin{array}{l}\text { "invention" pa- } \\
\text { tents }\end{array}$ & 0.977 & 1.000 & 0.930 & 0.840 \\
\hline $\begin{array}{l}\text { "new utility } \\
\text { model" patents }\end{array}$ & 0.985 & 0.930 & 1.000 & 0.961 \\
\hline $\begin{array}{l}\text { "new design" } \\
\text { patents }\end{array}$ & 0.931 & 0.840 & 0.961 & 1.000 \\
\hline
\end{tabular}

Table 2. Correlation coefficients of three types of patents, 1973(I)-2006(6)

\section{Empirical Results}

\section{IV.I Trends in Three Types of Patents}

Figs. I-4 show trends based on monthly data in Taiwan. The time period covered in this analysis is from January 1973 to June 2006. Total patent applications in Taiwan show a generally increasing trend and slope clearly upward for the three types of patents. Taiwan patents for "invention", "new utility model", and "new design" are generally very high, as given in Table 2. "New utility model" and "new design" patents have the highest correlation of $0.96 \mathrm{I}$, followed by "invention" and "new utility model" patents with 0.930. "Invention" and "new design patents rank third with a correlation coefficient of 0.840 . The three types of patents display a similar trend pattern and have co-movement phenomenon.

Figs. I-4 exhibit time-varying volatility of the monthly different patent types in Taiwan.. Interesting features in these series include the presence of clustering.' Clustering seems most noticeable during the later period of our samples. These features reflect the time-varying nature of volatility in patent applications, justifying the need for modeling conditional variances. If the Lagrange multiplier test of no ARCH effects clearly rejects the null hypothesis, accommodating time-varying volatility with an appropriate model would seem important. The Lagrange multiplier test of no ARCH effects shows that "new

\footnotetext{
I Every kind of patents ("invention", "new utility model” and “ new design " patents) shows the similar time series patterns.
}

design" patents exhibit time-varying volatility but "new utility model" and "invention" patents cannot reject the null hypothesis of no ARCH effects. One possible explanation is that there is no $A R C H$ of $G A R C H$ effect in "new utility model" and "invention" patent time series. Furthermore, "new utility model" and "invention" patents do not have volatility cluster characteristics like financial commodity markets. The next section focuses on volatility analysis of "new design" patents.

\section{IV.II Volatilities in Patent Applications}

\section{IV.II.I Full Sample Estimates}

The remainder of this paper models volatility in the logarithm of different patent types, namely the number of patents registered in Taiwan contrasted to that in the US. Undoubtedly, "new design" patents provide strong support for time-varying volatilities in the logarithm of patents, which justifies the need for modeling conditional variances. Models are defined in $\operatorname{GARCH}(I, I)$ and $\operatorname{EGARCH}(I, I)$ are estimated by the EViews 5.0 econometric software package using $40 \mathrm{I}$ monthly observations from January 1973 to June 2006. The estimations, based on QMLE, are presented in Table 3 and Table 4. The AR estimates range from 0.478 to 1.625 , and are significant in all two models and four different patent types, based on both asymptotic $t$-ratios. A similar comment applies for time trend coefficients, which range from 0.001 to 0.004 and are highly significant in all two cases and four different patent types. 
The second and fourth moment conditions notably satisfy both $G A R C H$ and EGARCH, suggesting that the QMLE are consistent and asymptotically normal. Results for "new utility" patents arise from an extremely high estimated $\alpha$ (or short run persistence). The outcome as the estimated long-run persistence, $\ddot{\mathscr{\theta}}+\ddot{\beta}$, is larger for "new design" patents than other patent types.

\begin{tabular}{|c|c|c|c|c|}
\hline & Total patents & "invention" patents & $\begin{array}{l}\text { "new utility model" } \\
\text { patents }\end{array}$ & $\begin{array}{l}\text { "new design" pa- } \\
\text { tents }\end{array}$ \\
\hline$\phi_{1}$ & $\begin{array}{l}0.834 * * * \\
(5.529)\end{array}$ & $\begin{array}{l}1.028 * * * \\
(6.551)\end{array}$ & $\begin{array}{l}0.54 I^{* * * *} \\
(4.591)\end{array}$ & $\begin{array}{l}0.478 * * * \\
(4.159)\end{array}$ \\
\hline$\phi_{2}$ & $\begin{array}{l}0.842 * * * \\
(29.276)\end{array}$ & $\begin{array}{l}0.742^{* * *} \\
(18.710)\end{array}$ & $\begin{array}{l}0.887^{* * *} \\
(34.092)\end{array}$ & $\begin{array}{l}0.893 * * * \\
(35.107)\end{array}$ \\
\hline$\phi_{3}$ & $\begin{array}{l}0.002 * * * \\
(5.415)\end{array}$ & $\begin{array}{l}0.003^{* * *} \\
(6.256)\end{array}$ & $\begin{array}{l}0.00 I^{* * * *} \\
(3.855)\end{array}$ & $\begin{array}{l}0.00 I^{* * * *} \\
(3.392)\end{array}$ \\
\hline$\omega$ & $\begin{array}{l}0.011 * * * \\
(5.115)\end{array}$ & $\begin{array}{l}0.018 * * * \\
(3.544)\end{array}$ & $\begin{array}{l}0.019 * * * \\
(5.682)\end{array}$ & $\begin{array}{l}0.00 I^{* * *} \\
(5.301)\end{array}$ \\
\hline$\alpha$ & $\begin{array}{l}0.491 * * * \\
(5.512)\end{array}$ & $\begin{array}{l}0.228 * * * \\
(2.873)\end{array}$ & $\begin{array}{l}0.419 * * * \\
(5.326)\end{array}$ & $\begin{array}{l}0.011 \\
(1.128)\end{array}$ \\
\hline$\beta$ & $\begin{array}{l}0.118 \\
(1.118)\end{array}$ & $\begin{array}{l}0.244 \\
(1.285)\end{array}$ & $\begin{array}{l}0.018 \\
(0.154)\end{array}$ & $\begin{array}{l}0.963 * * * \\
(98.877)\end{array}$ \\
\hline $\begin{array}{l}\text { ARCH test } \\
\text { (p-value) }\end{array}$ & 0.206 & $0.74 I$ & 0.161 & 0.04 I*** \\
\hline Second moment & 0.609 & 0.472 & 0.437 & 0.974 \\
\hline Fourth moment & 0.853 & 0.327 & 0.542 & 0.947 \\
\hline
\end{tabular}

Note: I. “****” denotes significance at the I\% level, “**”, at the $5 \%$ level.

2. $t$-values are in parentheses.

Table 3. GARCH results of three types of patents, 1973(I)-2006(6) 


\begin{tabular}{|c|c|c|c|c|}
\hline & Total patents & "invention" patents & $\begin{array}{l}\text { "new utility model" } \\
\text { patents }\end{array}$ & "new design" patents \\
\hline$\phi_{1}$ & $\begin{array}{l}1.034^{* * * *} \\
(7.289)\end{array}$ & $\begin{array}{l}1.625^{* * * *} \\
(8.339)\end{array}$ & $\begin{array}{l}0.490 * * * \\
(4.879)\end{array}$ & $\begin{array}{l}0.599 * * * \\
(6.356)\end{array}$ \\
\hline$\phi_{2}$ & $\begin{array}{l}0.804^{* * * *} \\
(29.233)\end{array}$ & $\begin{array}{l}0.596^{* * * *} \\
(12.188)\end{array}$ & $\begin{array}{l}0.898^{* * * *} \\
(39.311)\end{array}$ & $\begin{array}{l}0.865^{* * * *} \\
(40.337)\end{array}$ \\
\hline$\phi_{3}$ & $\begin{array}{l}0.002^{* * * *} \\
(6.94 I)\end{array}$ & $\begin{array}{l}0.004^{* * * *} \\
(8.146)\end{array}$ & $\begin{array}{l}0.001 * * * * \\
(3.897)\end{array}$ & $\begin{array}{l}0.00 I^{* * * *} \\
(4.409)\end{array}$ \\
\hline$\omega$ & $\begin{array}{l}-3.669 * * * \\
(-4.174)\end{array}$ & $\begin{array}{l}-2.646 * * * \\
(-2.902)\end{array}$ & $\begin{array}{l}-5.347 * * * \\
(-13.970)\end{array}$ & $\begin{array}{l}-0.019 \\
(-0.725)\end{array}$ \\
\hline$\alpha$ & $\begin{array}{l}0.580 * * * * \\
(5.691)\end{array}$ & $\begin{array}{l}0.297 * * * \\
(2.764)\end{array}$ & $\begin{array}{l}0.661^{* * * *} \\
(6.170)\end{array}$ & $\begin{array}{l}-0.068 \\
(3.525)\end{array}$ \\
\hline$\gamma$ & $\begin{array}{l}0.159 * * \\
(1.985)\end{array}$ & $\begin{array}{l}0.180 * * * \\
(2.428)\end{array}$ & $\begin{array}{l}0.141^{* * *} \\
(2.412)\end{array}$ & $\begin{array}{l}-0.040 \\
(-2.777)\end{array}$ \\
\hline$\beta$ & $\begin{array}{l}0.180 \\
(0.806)\end{array}$ & $\begin{array}{l}0.318 \\
(1.313)\end{array}$ & $\begin{array}{l}-0.342 \\
(-3.179)\end{array}$ & $\begin{array}{l}0.979 * * * \\
(210.797)\end{array}$ \\
\hline
\end{tabular}

Note: I. “****” denotes significance at the $1 \%$ level, “***” at the $5 \%$ level.

2. $t$-values are in parentheses.

Table 4. EGARCH results of three types of patents, 1973(I)-2006(6)

\begin{tabular}{|c|c|c|}
\hline & $\mathrm{GARCH}(\mathrm{I}, \mathrm{I})$ & $\operatorname{EGARCH}(\mathrm{I}, \mathrm{I})$ \\
\hline $\begin{array}{l}\text { Root mean squared error } \\
\left(\sqrt{\sum_{t=T+1}^{T+h}\left(\ddot{y}_{t}-y_{t}\right)^{2} / h}\right)\end{array}$ & 0.461 & 0.399 \\
\hline $\begin{array}{l}\text { Mean Absolute error } \\
\left(\sum_{t=T+1}^{T+h}\left|\ddot{\varphi}_{t}-y_{t}\right| / h\right)\end{array}$ & 6.707 & 5.675 \\
\hline $\begin{array}{l}\text { Theil inequality coefficient } \\
\left(\frac{\sqrt{\sum_{t=T+1}^{T+h}\left(\ddot{\boldsymbol{y}}_{t}-y_{t}\right)^{2} / h}}{\sqrt{\sum_{t=T+1}^{T+h} \ddot{\ddot{y}}_{t}^{2} / h}+\sqrt{\sum_{t=T+1}^{T+h} y_{t}^{2}}}\right.\end{array}$ & 0.036 & 0.031 \\
\hline
\end{tabular}

Table 5. Out-of-sample forecast statistics 


\begin{tabular}{|c|c|c|c|c|}
\hline Author & year & Data & Patent source & Main results \\
\hline $\begin{array}{l}\text { McAleer, et } \\
\text { al.. (2007) }\end{array}$ & $1975-1998$ & $\begin{array}{l}\text { Top I } 2 \text { foreign patent- } \\
\text { ing countries in the } \\
\text { USA: Australia, Cana- } \\
\text { da, France, Germany, } \\
\text { Italy, Japan, Korea, } \\
\text { Netherlands, Sweden, } \\
\text { Switzerland, Taiwan, } \\
\text { United Kingdom }\end{array}$ & $\begin{array}{l}\text { US Patent and Trade- } \\
\text { mark office }\end{array}$ & $\begin{array}{l}\text { Suitable model: } \\
\text { AR(I)-GJR(I,I): } \\
\text { Australia. } \\
\text { AR(I)-GARCH(I,I): } \\
\text { Netherlands, Switzerland. } \\
\text { AR(I)-EGARCH(I,I): } \\
\text { Canada, France, Italy, } \\
\text { Germany, Japan, Korea, Taiwan, } \\
\text { Sweden. }\end{array}$ \\
\hline $\begin{array}{l}\text { Marinova, D. } \\
(2002)\end{array}$ & $1975-1997$ & $\begin{array}{l}\text { Japan electronics and } \\
\text { vehicle/transport } \\
\text { equipment patents in } \\
\text { the USA }\end{array}$ & $\begin{array}{l}\text { US Patent and Trade- } \\
\text { mark office }\end{array}$ & $\begin{array}{l}\text { The asymmetric } A R(I)-G J R(I, I) \\
\text { model is found to be suitable for } \\
\text { motor vehicle/transport equipment. }\end{array}$ \\
\hline $\begin{array}{l}\text { Marinova, D. } \\
\text { McAleer, M. } \\
\text { (2003) }\end{array}$ & $1975-1997$ & US ecological patents & $\begin{array}{l}\text { US Patent and Trade- } \\
\text { mark office }\end{array}$ & $\begin{array}{l}\text { The asymmetric } A R(I)-G J R(I, I) \\
\text { model is found to be suitable for } \\
\text { modeling the ecological patent share } \\
\text { in the USA. }\end{array}$ \\
\hline $\begin{array}{l}\text { Chan et al. } \\
(2004)\end{array}$ & $1975-1997$ & US electronics patents & $\begin{array}{l}\text { US Patent and Trade- } \\
\text { mark office }\end{array}$ & $\begin{array}{l}\text { The asymmetric } A R(I)-G J R(I, I) \\
\text { model is found to be suitable for } \\
\text { modeling the electronics patent share } \\
\text { in the USA. }\end{array}$ \\
\hline $\begin{array}{l}\text { Chan et al. } \\
(2004)\end{array}$ & $1975-1997$ & $\begin{array}{l}\text { Top I } 2 \text { foreign patent- } \\
\text { ing countries in the } \\
\text { USA: Australia, Cana- } \\
\text { da, France, Germany, } \\
\text { Italy, Japan, Korea, } \\
\text { Netherlands, Sweden, } \\
\text { Switzerland, Taiwan, } \\
\text { United Kingdom }\end{array}$ & $\begin{array}{l}\text { US Patent and Trade- } \\
\text { mark office }\end{array}$ & $\begin{array}{l}\text { The asymmetric } A R(I)-G J R(I, I) \\
\text { model is found to be suitable for } \\
\text { Australia and Japan. The most appro- } \\
\text { priate model for Germany was sym- } \\
\text { metric } A R(I) \text {-GARCH }(I, I) \text { model. }\end{array}$ \\
\hline
\end{tabular}

Table 6. Previous analysis of Trends and Volatility

All the $\beta$ estimates for EGARCH are less than one in absolute value, implying that all moments exist and that the QMLE are likely consistent and asymptotically normal. No parametric restriction exists for conditional volatility to be positive, as EGARCH is a logarithm model of conditional variances. The estimates of EGARCH suggest that sign effect $(\gamma)$ is less important than size effect $(\alpha)$ in cases of "invention" patents and "new utility model" patents, and is statistically significant. $\beta$ estimates from EGARCH $(I, I)$ for "invention" and "new utility model" patents are not statistically significant.
However, the sign effect $(\gamma)$ of "new design" patents are lower than size effect $(\alpha)$. This indicates that sign effects have larger impacts than size effects on conditional variances. As Engle's (1982) LM test does not reject the null hypothesis of $A R C H$ effect absence for "invention" and "new utility model" patent types, one possible explanation is that there is no $\mathrm{ARCH}$ or GARCH effect in the series. Figs. 5-6 show actual, fitted residuals in the full sample. Models suitable for our sample are decided by out of sample evidence discussed in the next section. 
Figure I. Total Taiwan patents by date of application

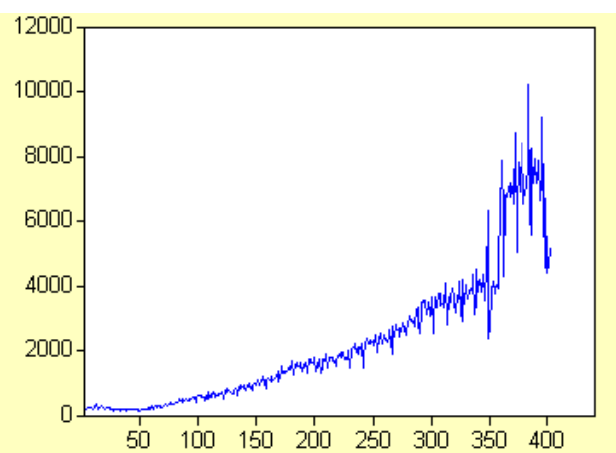

Figure 3. "New utility model" patents by application date

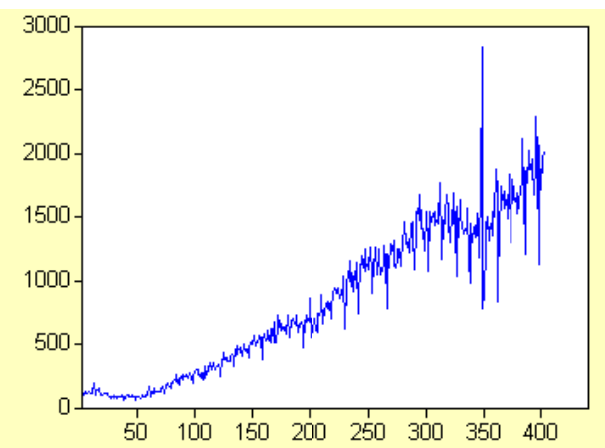

Figure 5. Fitted, actual data for $\mathrm{GARCH}$ model

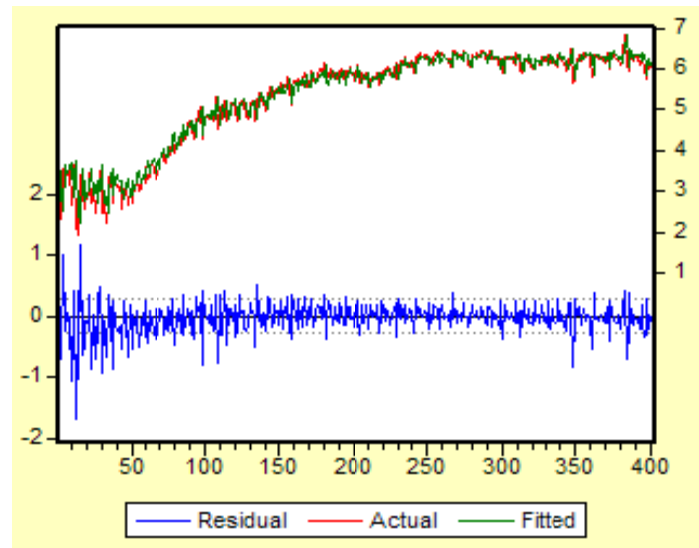

Figure 2. "invention" patents by date of application

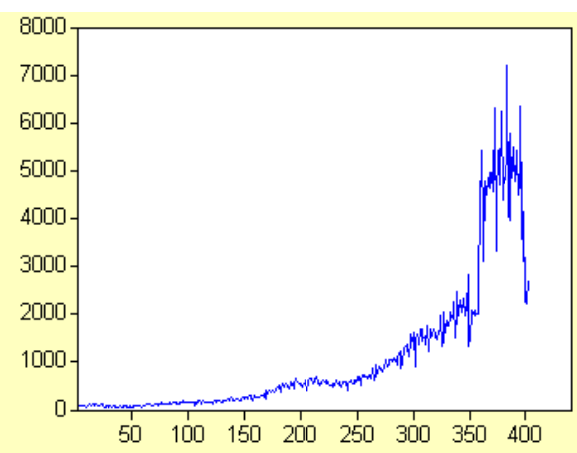

Figure 4. "New design" patents by application date

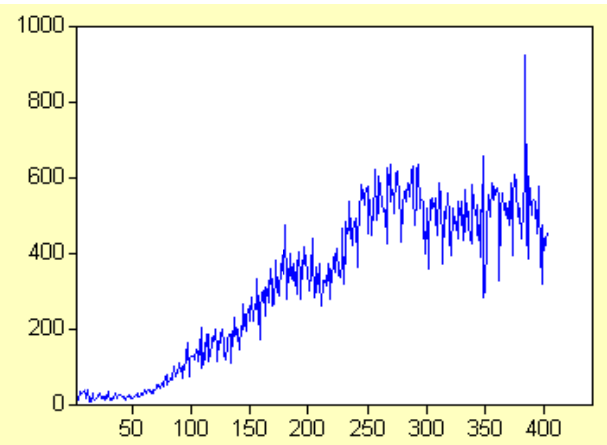

Figure 6. Fitted, actual data for EARCH model

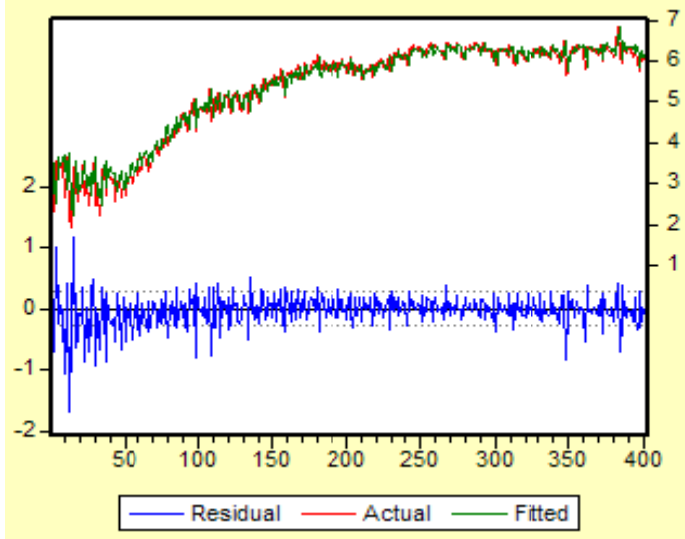


Figure. 7. Rolling $\mathrm{GARCH}(\mathrm{I}, \mathrm{I})$ estimates
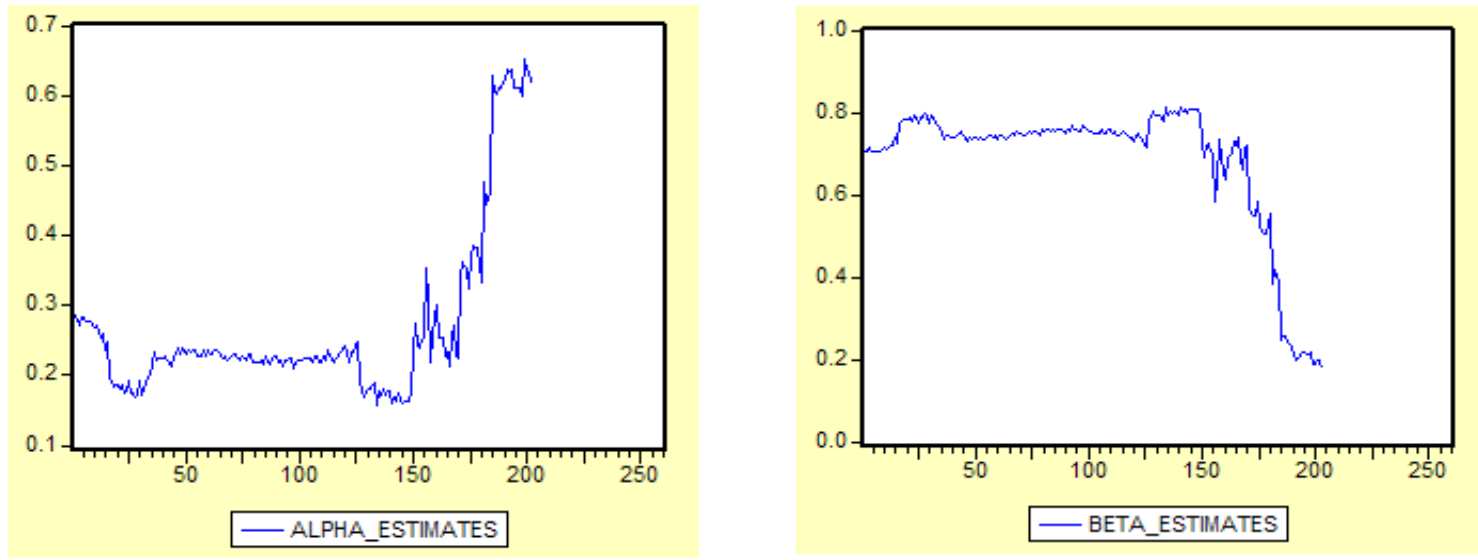

Figure 8. Rolling EGARCH $(I, I)$ estimates
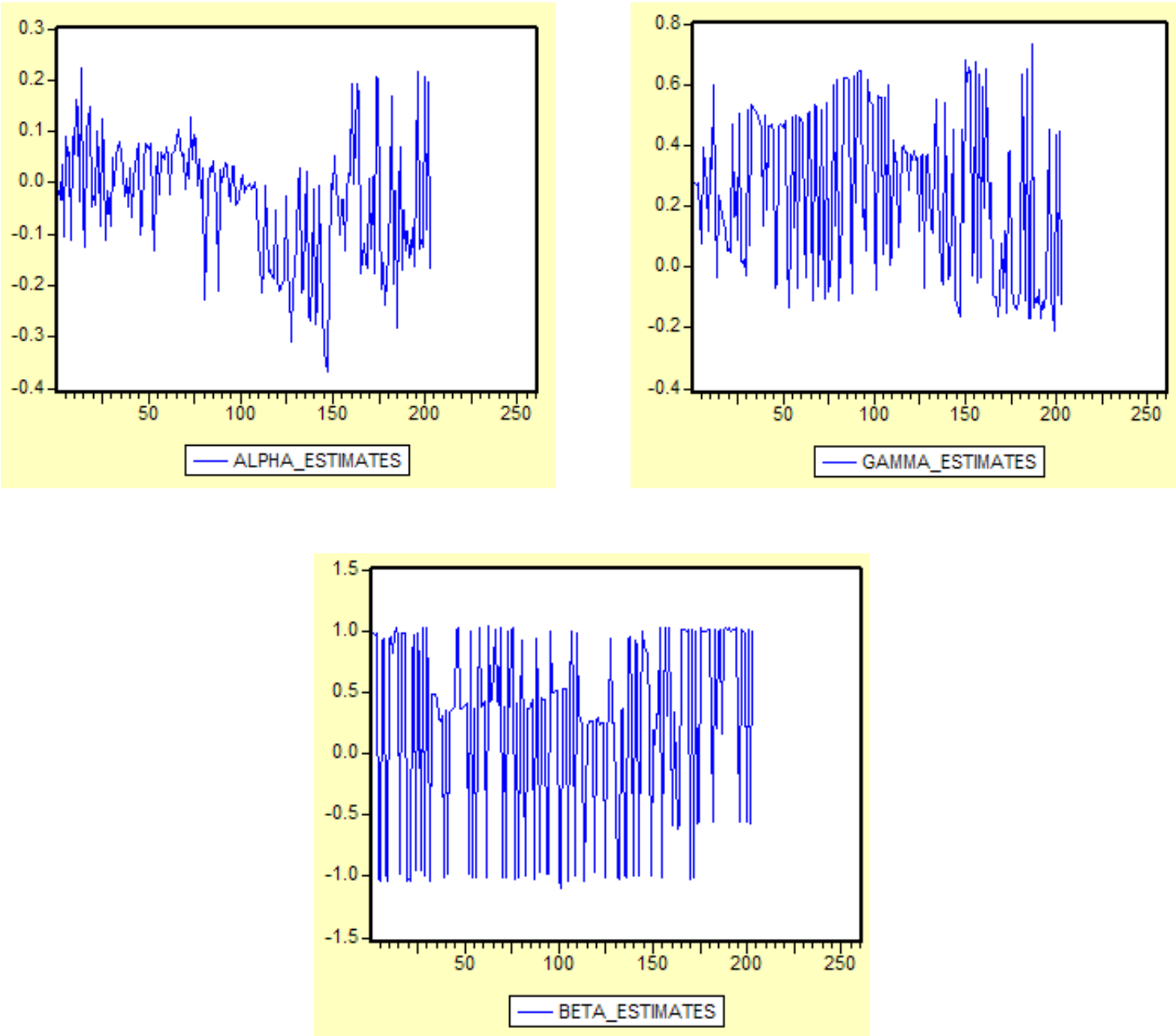

ISSN: 07I8-2724. (http://www.jotmi.org) 


\section{IV.II.II Rolling Estimates}

Rolling estimates with a 200-window size and their associated moment conditions for each model, are given in Figs. 7-8 to examine the impacts of each observation on model estimates.

In the case of $\mathrm{GARCH}(\mathrm{I}, \mathrm{I})$, the $\alpha$ estimates exhibit an upward trend, with a mean of 0.271 . The period between July 2004 and June 2006 is particularly interesting, when $\alpha$ estimates increase from 0.33 to 0.62 . This dramatic movement has some equally dramatic counterparts in the $\beta$ estimates. In July 2004 , the $\beta$ estimates decrease from 0.55 to 0.38 , and remain low for many months. Overall, the mean $\beta$ is 0.68 , which is lower than its full sample counterpart reported in Table 3.

The $\alpha$ estimates of EGARCH $(I, I)$ exhibit substantial fluctuations in the full rolling samples, ranging from -0.36 to 0.22 , with a mean of -0.04 . Both the $\gamma$ and $\beta$ estimates exhibit similar patterns, with a mean of 0.23 and 0.24 , respectively. The movements in the $\beta$ estimates are particularly interesting, fluctuating dramatically in our rolling samples. These variations explain the low mean of the $\beta$ estimates, and reflect difficulties in estimating the EGARCH model precisely.

\section{IV.III Forecasts}

This research produces a dynamic forecast over the January 1973 to June 2006 sample, to obtain a robust and suitable model to capture patent dynamics. The dynamic forecast period is constructed for the period from August 1989 to September 2006. We examine the actual versus fitted values to show out-of-sample forecast ability by creating the following three forecast error statistics:

$$
\begin{aligned}
& \sqrt{\sum_{t=T+1}^{T+h}\left(\ddot{\emptyset}_{t}-y_{t}\right)^{2} / h} \\
& \sum_{t=T+1}^{T+h}\left|\ddot{y}_{t}-y_{t}\right| / h
\end{aligned}
$$

ISSN: 07I8-2724. (http://www.jotmi.org) Journal of Technology Management \& Innovation ( Universidad Alberto Hurtado, Facultad de Economía y Negocios

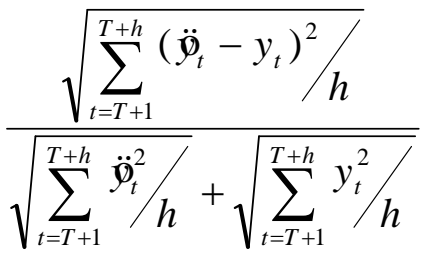

Where the forecast sample is $j=T+1$, i.e. $h=1$, and denotes the actual and forecasted value in period $\mathrm{t}$ as $y_{t}$ and $\ddot{\emptyset}_{t}$, respectively. These measures compare forecasts for the same series across different models; the smaller the error, the better the forecasting ability of that model according to that criterion. Equation (8) means the Theil inequality coefficient always lies between zero and one, where zero indicates a perfect fit. The residual, fitted, and actual situation is shown in Table 3 and the three statistics are calculated in Table 3. No matter what statistics we choose, $\operatorname{EGARCH}(I, I)$ is the most suitable volatility model to capture patent dynamics in Taiwan.

\section{Conclusion}

This paper presents an overview of patent trends and volatilities in the logarithm of patent applications from January 1973 to June 2006. Similarly, the trends and volatilities have almost analyzed in registered US patents for the top 12 foreign patenting countries in the USA from 1975 to 1988. We have summarized the several recent empirical studies in Table 6. However, variations in the patent share in previous empirical studies do not consider different patent quality in a given patent system. We separate total patent applications in Taiwan patent systems into three heterogeneous quality patent types. This work examines the time-varying nature of trends and volatilities of respective patent types, using monthly data. Three different patent types exhibit an increasing trend. "Invention" and "new utility model" patents fail to reject the null hypothesis of no ARCH effects. "New design" patents show high and persistent volatility. The samples exhibit asymmetric effect through the EGARCH model. Full sample results satisfy second and fourth moment conditions. The dynamic paths of rolling estimates provide important information about individual observation impact on model estimates. The EGARCH $(I, I)$ model is the most suitable volatility model to cap- 
ture patent application dynamics, based on out-ofsample forecasts.

In conclusion, a primary aim of this paper is to present an econometric analysis of the symmetric and asymmetric volatility for different patent quality in Taiwan. This is a crucial first step to measure risk and return on intellectual property. From a policy perspective, the understanding of volatility in patenting can enable governments to anticipate industry policy in relation to this new class of emerging technologies. The policy implications also can include removal of financial barriers to commercialization of patents and various forms of assistance to innovating companies and individuals.

\section{References}

CHAN, R., Marinova, D., McAleer, M. (2004) Trends and Volatilities in Foreign Patents Registered in the USA. Applied Economics, 36, 585-592.

CHAN, R. Marinova, D., McAleer, M. (2004) Modelling the Asymmetric Volatility of Electronics Patents in the USA, Mathematics and computers in Simulation,64, 169184.

HALL, B. H. 2004. Innovation and Diffusion, NBER working paer \#10212.

HALL, B. H., Jaffe, A., Trajtenberg, M. (2002) The NBER Patent Citations Data File: Lessons, Insights and Methodological Tools, in A. Jaffe and M. Trajtenberg (eds), Patents, Citations and Innovations, Cambridge, MA: The MIT Press.

HALL ,B. H., Jaffe, A., Trajtenberg, M. (2005) Market Value and Patent Citations, Rand Journal of Economics, 36, 16-38.

HOTI, S., McAleer, M. (2006) How does Country Risk Rffect Innovation? An Application to Foreign Patents Registered in the USA, Journal of Economic Surveys, 20, 69I-7I4.

GOEL, R. K. (1999) Economic Models of Technological Change: Theory and Application, Quorum Books, Westport, Connecticut, p. I3I.
GRILICHES, Z. (1990) Patent Statistics as Economic Indicator: A Survey, Journal of Eonomic Literature, 28, |66|-707.

LING, S., Li, W. K. (1997) On Fractionally Integrated Autoregressive Moving-average Models with Conditional Heterosckedasticity, Journal of the American Statistcal Association, 92, I I84-I 194.

LING, S., McAleer, M. (2002a) Necessary and Sufficient Moment Conditions for the $\operatorname{GARCH}(r, s)$ Models, Econometric Theory, 18, 722-729.

LING, S., McAleer, M. (2002b) Stationary and the Existence of Moments of a Family of GARCH Processes, Journal of Econometrics, 106, 109-I 17.

LING, S., McAleer, M. (2003) Asymptotic Theory for a Vector ARMA-GARCH Model, Econometric Theory, 19, 278-308.

MARINOVA, D. (200I) Eastern European Patenting Activities in the USA, Technovation, 2I, 57I-584.

MARINOVA, D., McAleer, M. (2002) Trends and Volatility in Japanese Patenting in the USA: An Analysis of the Electronics and Transport Industries, Scientometrics, 55, I7|-187.

MARINOVA, D., McAleer, M. (2003) Modelling Trends and Volatility in Ecological Patents in the USA, Environmental Modelling and Software, 18, 195-203.

MCALEER, M., Chan, F., Marinova, D. (2007) An Econometric Analysis of Asymmetric Volatility: Theory and Application to Patents, Journal of Econometrics, 139, 259. 284.

NELSON D. B. (1991) Conditional Heteroscedasticity in Asset Returns: A New Approach, Econometrica, 59, 347370.

PATEL, P., Pavitt, K. (1995) Divergence in Technological Development among Countries and Firms, in Technical Change and the World Economy: Convergence and Divergence in Technology Strategies (Ed.) J. Hagedoorn, Edward Elgar, Aldershot, |47-181. 
PAVITT, K. (1998) Uses and Abuses of Patent Statistics, in Handbook of Quantitative Studies of Science and Technology (Ed.) A. F. J. van Raan, Elsevier, Amsterdam, 509-536.

SHEPHARD, N. (1996) Statistical Aspects of ARCH and Stochastic Volatility, in: O. E. Barndorff-Nielsen, D. R. Cox, C. V. Hinkley (Eds.), Statistical Models in Econometrics, Finance and Other Fields, Chapman and Hall, London, I-67.

\section{Biography}

Wen-Cheng Lu received his MS degree at National Taiwan University with a major in Financial Economics and Ph.D degree in National Central University with a major in Industrial Economics. He is an assistant professor at the Department of Economics, Ming Chuan University. His research interests include knowledge management, productivity, and applied econometrics.

Jong-Rong Chen is a professor at graduate Institute of Industrial Economics in National Central University, Taiwan. His research interests include technology management, industrial economics, and productivity. Dr. Chen has published numerous articles in, to name a few, Research Policy, Applied Economics, and Journal of the Japanese and International Economies.

I-Hsuan Tung is a Ph.D. candidate at graduate Institute of Industrial Economics in National Central University, Taiwan. She is a research assistant in graduate Institute of Industrial Economics in National Central University. Her research interests include patent and innovation management, R\&D investment, and intellectual property rights. 